\title{
DEEP X-RAY TREATMENT
}

\author{
By P. A. FLOOD, M.R.C.S., L.R.C.P., D.M.R. \\ (Royal Cancer Hospital [Free]). (On Active Service.)
}

A review of any group of cases of carcinoma of the lung, whether treated by X-rays or by any other method of treatment, reveals at once that the lung is one of the sites of cancer where a cure of the disease is, at present, very rarely obtained.

It follows, therefore, that in all cases of carcinoma of the lung treatment must be regarded as being a palliative measure. The only exceptions are, that very small percentage of all cases in which either a lobectomy or a pneumonectomy can be performed, and in which there is no clinical evidence of glandular involvement. In these few cases a permanent result can be hoped for. Authenticated cases of even five-year cure by X-rays are very rare, and X-ray treatment must always be regarded as a palliative measure; weakening or damaging effects must be avoided as far as possible, and treatment restricted to those cases in which palliation is possible.

From the theoretical and histological point of view there is no valid reason why a carcinoma of the lung should not be cured by an adequate dose of $\mathrm{X}$-rays as frequently as is carcinoma at other sites in the body.

There are probably three main reasons why a permanent cure by X-ray therapy is so rarely recorded, firstly the silent nature of the disease in its early stage, secondly the very frequent occurrence of metastases at an early stage, and thirdly the inaccessibility of these tumours and their immediate glandular drainage. For a matter of some weeks or months a primary carcinoma of the lung may produce no symptoms at all. The average age at which these tumours occur is fifty years of age, the commonest early symptoms of cough and dyspnoea at this age are usually no new experience to the patient, and are apt to be disregarded for some time as being trivial. It is usually only after some months that loss of weight, increasing lassitude, pain or haemoptysis cause the patient to seek advice. In other cases in which perhaps early advice is sought the relatively slight symptoms of cough and dyspnoea are regarded and treated as a chronic bronchitis, especially in view of the patient's age, and vital weeks are lost. A thorough examination in every case of persistent cough of more than three weeks duration would lead to the discovery of more operable cases. A valuable aid in the early diagnosis of carcinoma of the lung, often before there is anything visible on X-ray examination of the chest, is the examination of the sputum for carcinoma cells by the late Professor Dudgeon's method.

In over 90 per cent. of cases the primary growth occurs in the wall of one of the large bronchii; primary growths of the trachea, the intermediate or peripheral areas of the lung are rare. Both local and distant metastases occur at an early stage. The short and direct lymphatic path to the hilar group of glands renders these and the mediastinal glands liable to infection at a very early stage; later by lymphatic spread the abdominal and supraclavicular glands may become infected. The marked vascularity of the tissues immediately surrounding these growths makes erosion into a vessel with consequent blood borne metastases a frequent and sometimes early occurrence. These distant metastases occur commonly in the liver, kidney, brain, lungs and bones. In such cases X-ray therapy cannot be considered to be even palliative, but merely a placebo, and as such should not be used.

The inaccessibility of these tumours is the particular problem of the radiotherapist. In the treatment of these, as also of other deep-seated tumours, some progress has been made in recent years. The problem raised is that of giving an effective dose to a chosen volume at a given depth, without causing undue damage to intervening structures, and the assessment of that volume so as to include the tumour and its probable extension. In the case of carcinoma of the lung the area covered by the tumour and its immediate glandular drainage is both large and inconvenient in shape. Any volume of more than ro cubic centimetres presents difficulties. In primary carcinoma of the lung the exact extent of the disease is difficult to determine, and it rarely lies within a volume of this size.

Three niain factors have contributed to the progress that has been made in high voltage $\mathrm{X}$-ray therapy in recent years, they are (I) higher voltages, (2) greater accuracy of beam direction, and (3) greater accuracy of dosage estimation. They are all physical in character, and the therapist is indebted to the physicists for the considerable contribution they have made to each. 
Higher voltages up to one million volts are now in clinical use, and in the years immediately following the war very much higher voltages can be expected. These higher voltages have added considerably to the " percentage depth dose "- that is to the dose given at a depth relative to that given to the skin and intervening structures.

Beam direction.-Many ingenious mechanical means have been devised in recent years to ensure accurate direction of the beam of X-rays at the tumour, and exact maintenance of the position of tube and patient during treatment. These have enabled smaller fields to be used without risk of missing the tumour site, and thereby eliminated unnecessary and harmful radiation. Multiple fields not only concentrate the dose at the chosen depth, but also the small size of the fields reduces the "integral dose", that is the total radiation absorbed by the body, and minimises the general effects of irradiation such as effects upon the blood.

The conception of "volume distribution" of radiation, the simple and accurate means by which the amount of radiation absorbed can be measured throughout the whole volume irradiated, has led to considerable improvement in the even distribution of radiation throughout the tumour site, with consequent avoidance of dangerous high or low areas of dosage.

Analysis of Results.-An analysis of 70 consecutive cases of carcinoma of the lung seen in the radiological department of the Royal Cancer Hospital in the four-year period from I937 to 1940 is given in Table $\mathrm{I}$.

\section{Table 1}

Seventy consecutive cases of primary carcinoma of the lung, 1937-1940

Died, 69. Alive one with no evidence of active growth 2 years 2 months after treatment.

\begin{tabular}{|c|c|c|c|c|c|c|c|c|c|}
\hline & $\begin{array}{c}\text { Age in } \\
\text { Years }\end{array}$ & $\begin{array}{c}\text { Duration of } \\
\text { symptoms } \\
\text { before } \\
\text { treatment }\end{array}$ & \multicolumn{2}{|c|}{$\begin{array}{l}\text { Duration from } \\
\text { first symptom } \\
\text { to death }\end{array}$} & $\begin{array}{c}\text { Survival } \\
\text { after } \\
\text { treatment }\end{array}$ & Sex & $\begin{array}{l}\text { General } \\
\text { Health }\end{array}$ & $\begin{array}{l}\text { Histo- } \\
\text { logic- } \\
\text { ally con- } \\
\text { firmed }\end{array}$ & $\begin{array}{l}\text { Average } \\
\text { dose to } \\
\text { tumour }\end{array}$ \\
\hline Maximum & 74 & I yr. 9 mths. & \multicolumn{2}{|c|}{ I yr. I I mths. } & $\begin{array}{c}2 \text { yrs. } 2 \\
\text { mths. }\end{array}$ & $\underset{60}{\text { Males }}$ & $\underset{\mathbf{I}}{\text { Good }}$ & $63 \%$ & $4,200 \mathrm{r}$ \\
\hline \multirow[t]{2}{*}{ Minimum } & 19 & 3 mths. & \multicolumn{2}{|l|}{4 mths. } & $\begin{array}{l}\text { Less than } \\
\text { I mth. }\end{array}$ & $\underset{\text { Io }}{\text { Females }}$ & $\begin{array}{c}\text { Fair } \\
29\end{array}$ & & \\
\hline & & & $\begin{array}{l}\text { Treated } \\
\text { cases }\end{array}$ & $\begin{array}{c}\text { Not } \\
\text { treated }\end{array}$ & \multirow[b]{2}{*}{7 mths. } & & $\begin{array}{c}\text { Poor } \\
40\end{array}$ & & \\
\hline Average & 49 & $5 \frac{1}{2}$ mths. & I I mths. & 6 mths. & & & & & \\
\hline
\end{tabular}

Though there is a wide range of age incidence the average age of 49 years is in agreement with other published series. The average duration of symptoms before treatment of five and a half months compares with figures published by Tchaperoff (St. Thomas's Hospital Reports, I937), in which series he found that 38 per cent. had symptoms from 2 to 5 months before treatment, and 27 per cent. from 6 to ro months before treatment. The average duration from first symptom to death and the average duration of survival after treatment are adversely affected in this series of cases by the high percentage ( 55 per cent.) who were in poor health when first seen. It is indeed questionable whether X-ray treatment should be undertaken in patients whose health at the outset is poor. Sixteen treated cases in this series (23 per cent.) survived for periods exceeding one year, and most of these were in fair health when treatment was undertaken.

The ratio of six males to every one female is not unusually high, a ratio of as high as fifteen to one has been found in some series. The one case in the series that is still alive and clinically free from recurrence after more than two years was in every way a typical case; a male aged 58 years, in fair health, in whom the growth was histologically confirmed following bronchoscopy, the tumour area received an average dose of $5,000 \mathrm{r}$.

Value of X-ray treatment.-A statistical survey of the results of X-ray treatment of primary carcinoma of the lung, recording as it does practically Ioo per cent. mortality within 
Table 2

\begin{tabular}{|c|c|c|}
\hline & \multicolumn{2}{|c|}{$\begin{array}{l}\text { Average duration from } \\
\text { first symptom to death. }\end{array}$} \\
\hline & Treated cases. & $\begin{array}{c}\text { Not treated } \\
\text { cases. }\end{array}$ \\
\hline 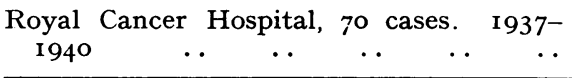 & I I months & 6 months \\
\hline $\begin{array}{cccccc}\text { Tchaperoff, St. Thomas's Hospital reports, } \\
\text { I937 } & \ldots & \ldots & \ldots & \ldots & \ldots\end{array}$ & Io months & 5 months \\
\hline $\begin{array}{c}\text { Farberov and Baslow, American Journal of } \\
\text { Röentgenology, I94I } \\
\text {. }\end{array}$ & 8 months & $5 \frac{1}{2}$ months \\
\hline
\end{tabular}

two years is apt to give a false impression of the value of X-ray treatment, or at least it does not bring out the benefits that can be obtained from such treatment.

It should be remembered that cases submitted for X-ray treatment are inoperable cases, either on account of the extent of the growth, or on account of the patients' poor general condition. The treatment of primary carcinoma of the lung by high voltage X-ravs is a palliative measure, and as such its object is the relief of symptoms rather than the prolongation of life. The realisation by a patient that he has " chest trouble," even though he may not understand its nature, so frequently causes the patient very grave concern and anxiety, especially when accompanied as it so often is in carcinoma of the lung, by increasing weakness. A great deal is achieged towards the well-being of these cases if relief is given from symptoms of pain, recurrent haemorrhage, dyspnoea and cough. In the majority of cases an adequate dose of X-rays will alleviate such symptoms. Many cases are for a time rendered symptomless, they gain weight, and their general health improves. In a number of cases they are able to live a normal life, and their working capacity is preserved.

Looked at from another point of view, a patient at the age of fifty years who knows he has malignant disease, so often attaches to a further six months of normal life a value out of all proportion to its length of time.

Treatment.-It cannot be said that there are any recognised standard techniques in the treatment of lung carcinoma; each case requires individual planning. The highest available kilovoltage should be used. A dose of 5,000 $\mathrm{r}$. in four weeks represents an adequate average dose, but the total dose and the time over which it is given must depend on the patient's general fitness and reaction. Very poor general health and marked anaemia are contra-indications to treatment.

These cases are rather subject to X-ray sickness and nausea, but if the dose is diminished and adequate counter measures taken treatment need not be stopped. They also frequently show a marked fall in the white cell count towards the end of the course of treatment. Provided the total white cell count is not below. 2,000 per c.cm. or the lymphocytes below 250 per c.cm. treatment may be continued, the white cell count will recover rapidly when treatment ceases. An even moderate fall in the red cell count or haemoglobin, however, is often an indication that treatment cannot be carried to a full dose. In every case a blood count should be taken before and at least weekly during treatment.

Cases that survive more than one year after treatment will develop well-marked fibrosis of the area of the lung treated, it is therefore important to restrict the area of high dosage to a safe minimum and to avoid the opposite lung as far as possible.

In this short survey of the X-ray treatment of carcinoma of the lung and its difficulties, stress has been laid on the fact that it is a palliative measure. Any future improvement in the cure rate of this form of cancer will come, not as the result of X-rays alone or of surgery alone, but more probably as a result of the combination of both. If surgery can render these growths accessible to treatment by a modern medium voltage X-ray tube, or if high-voltage X-rays can render some inoperable growths operable, permanent results may be expected in many more cases. 